\title{
Evaluation of performance factors of FMS by combined decision making methods as AHP, CMBA and ELECTRE methodology
}

\author{
Vineet Jain $^{a^{*}}$ and Puneeta Ajmera ${ }^{b}$
}

${ }^{a}$ Department of Mechanical Engineering, Amity University Haryana, Gurgaon, India

${ }^{b}$ Department of Hospital Administration, Amity Medical School, Amity University Haryana, India

\section{H R O N I C L E A B S T R A C T}

Article history:

Received: November 28, 2018

Received in revised format: No-

vember 29, 2018

Accepted: January 16, 2019

Available online:

January 17, 2019

Keywords:

FMS

Decision making

Combinatorial mathematics

$A H P$

$C M B A$

ELECTRE
Present research is aimed to analyze the performance factors of flexible manufacturing systems by combined decision-making methodologies like analytical hierarchy process (AHP), combinatorial mathematics-based approach (CMBA) and improved ELECTRE. Six variables affecting the three factors of performance of flexible manufacturing systems viz. productivity, flexibility and quality are considered for the evaluation of performance factors. The weights of the attributes are calculated with AHP and the index score is calculated with CMBA methodology. CMBA methodology is the fusion of AHP and GTMA. ELECTRE approach has been used for the outranking of factors. The results show that productivity had the maximum impact on the performance of manufacturing systems. A high Spearman's rank correlation also exists among the methods used.

\section{Introduction}

In the present volatile market scenario, product specifications are changing vary rapidly. Therefore, to cope up with the market conditions manufacturing system should be capable enough to assist revamps as speedily as possible. But there is a conflict in the production system that with an increase in the variety there is a decrease in the productivity. So to accommodate this, "flexible manufacturing system (FMS)" is a good solution to maintain the variety as well as productivity. FMS is a type of advanced manufacturing system which has the flexibility to quickly configure different kinds of products for production. Jain and Raj (2017) defined FMS as "an integrated, computer-controlled complex arrangement of automated material handling devices and numerically controlled (NC) machine tools that can simultaneously process medium sized volumes of a variety of part types". According to Ruiz et al. (2009) "FMS consists of a number of CNC machine tools, robots, material handling, automated storage and retrieval system, and computers or workstations". David Williamson, a British engineer developed

\footnotetext{
* Corresponding author. Tel.: +918901510570

E-mail address: vjdj2004@gmail.com (V. Jain) 
the concept of FMS in 1960 where a group of machines is clustered and it works 24 hours a day. Based on this concept, first FMS was commissioned in US with Ingersoll-Rand Company (Luggen, 1991; Maleki, 1991).

FMS is a complex system due to the inter-relationships of various components of manufacturing system. So, it is very hard to compute the performance measures of the FMS. Vineet Jain and Puneeta Ajmera (2019) used MOORA and WEDBA methods for ranking of FMS flexibility. Vineet Jain and Raj (2016) and Khanchanapong et al. (2014) defined the three factors of performance of FMS i.e. productivity, flexibility, quality. The main focus of the FMS is to enhance productivity, flexibility and quality (Gunasekaram et al., 1998). Vineet Jain (2018) discussed the performance factors by MOORA and PSI methodology and found that the productivity is the main critical success factor in the manufacturing system.

In this paper, six variables which effect the performance of FMS have been recognized through the published literature along with the three factors of performance of FMS. Six variables are exhibited in Table 1.

Table 1

Name of performance variables

\begin{tabular}{ccc}
\hline Sr. No. & Name of Variable & Reference \\
\hline 1 & Automation & Gothwal and Raj (2016); Jain and Raj (2013a) \\
2 & Use of automated material handling devices & Jain and Raj (2014b); Umar et al. (2015) \\
3 & Increased machine utilization & Raj et al. (2012) \\
4 & Manufacturing lead time and set up time & Jain and Raj (2013c); Jain and Raj (2015a) \\
5 & Flexible fixturing & Jain and Raj (2015c) \\
6 & Scrap percentage & Ravikumar et al. (2015), Jain and Soni (2018) \\
\hline
\end{tabular}

These factors are ranked by MADMs "multiple attribute decision making methods", i.e. AHP "analytical hierarchy process", CMBA "combinatorial mathematics-based approach" and improved ELECTRE "elimination et choix traduisant la realité". These MADM methods can handle qualitative as well as quantitative attributes in the problems where decisions are to be made. The aim of the arranging the performance factors in the order of ranking is to help the manufacturing managers and the researchers so that they can better concentrate on the performance of FMS. The primary objective of the current research it to arrange the performance factors of FMS in hierarchical order taking into account the variables affecting the performance of FMS by the combined MADM techniques. The first section includes the introduction about FMS. In the second section, combined "multiple attribute decision making" (MADM) techniques are discussed. The performance factors are ranked and presented in section three. Discussion of the results and conclusion are included in section four.

\section{Combined MADM "Multiple Attribute Decision Making" Methodologies}

In this work, the methodologies used for ranking of the factors are:

1. Analytical hierarchy process (AHP)

2. Combinatorial mathematics-based approach (CMBA)

3. Improved elimination et choix traduisant la realité (ELECTRE)

\subsection{AHP Methodology}

AHP methodology was developed by Saaty $(1994,2000)$ in which a problem for which the decision has to be made is broken down into objectives, attributes and alternatives as a hierarchy of the system. It is a useful approach as it considers a number of functional features (Triantaphyllou, 2013). In this methodology, priorities are set for different alternatives and the criteria are used to judge them. The AHP approach has been used by different researchers in different areas. Singh and Sharma (2014) used 
AHP for comparing the supply chain processes of the three Indian car manufacturing factories based on three attributes i.e. assets, processes, and performance. Yang and Chen (2004) proposed a framework for the evaluation of performance of quality. Pun, Chin, and Yiu (2010) used AHP to evaluate the performance of a new product. Liu et al. (2005) constructed a model to evaluate performance. Vineet Jain and Raj (2013c) have done the ranking of flexibilities of FMS by MADM methods. Bayazit (2005) used AHP for decision making in FMS. Jain and Raj used AHP to compute the weights of attributes and used different MADM methods for ranking of flexibilities (Vineet Jain and Raj, 2013b, 2014a, 2015b). Dağdeviren (2008) used AHP for equipment selection. Taha and Rostam (2012) used AHP with PROMETHEE to select the machine tools. Al-Ahmari (2008) used AHP for the evaluation of advanced manufacturing system.

The plan of AHP methodology is given below:

1. The objective of AHP and the assessment criteria are determined first followed by the development of a hierarchical structure where objective is placed on the top, criteria is placed at the middle level and finally alternatives at the lowest level.

2. The significance of various criteria is determined in reference to the objective.

3. A pairwise comparison matrix is developed for the relative importance.

4. When the comparison is made with the attribute itself, 1 is allocated and therefore all the entries at the diagonal are one. The other numbers like 3,5, 7, and 9 signify the importance level.

5. Finally the weight (wj) of each attribute is determined (Vineet Jain \& Raj, 2013c)

6. After this, the values of attributes are normalized. Let $x_{i j}$ is the normalized value of $d_{i j}$ for attribute $\mathrm{j}$ of alternative $\mathrm{i}$. so the following equation is used for normalization of data.

$$
\begin{aligned}
& \left.x_{i j}=\frac{d_{i j}}{\max _{j}\left(d_{i j}\right)} ; \quad \text { if } \mathrm{j} \text { th attribute is beneficial }\right) \\
& \left.x_{i j}=\frac{\min _{j}\left(d_{i j}\right)}{d_{i j}} ; \quad \text { if } \mathrm{j} \text { th attribute is non beneficial }\right)
\end{aligned}
$$

7. The next step is to obtain the overall or composite performance scores for the alternatives by multiplying the relative normalized weight $\left(\mathrm{w}_{\mathrm{j}}\right)$ of each attribute with its corresponding normalized weight value for each alternative (obtained in step3), and summing over the attributes for each alternative.

\subsection{Combinatorial mathematics based approach (CMBA) Methodology}

Combinatorial mathematics based approach (CMBA), it is the amalgamation of two MADM approaches i.e. AHP "analytical hierarchy process" and GTMA "graph theory and matrix approach" (Rao, 2013). CMBA method has the ability to handle the subjective and as well as objective type of attribute data. The following steps are taken to apply CMBA (Rao, 2013):

Step 1: Develop a decision matrix:

A decision matrix is the accumulation of data of attributes for each alternative whether it is subjective or objective. If attribute data is subjective then it is required to convert it in objective by using fuzzy scale i.e. linguistic terms are converted into crisp numbers. The eleven point fuzzy scale used for converting fuzzy value of attributes into corresponding crisp scores is shown in Table 2 and Fig. 1. 


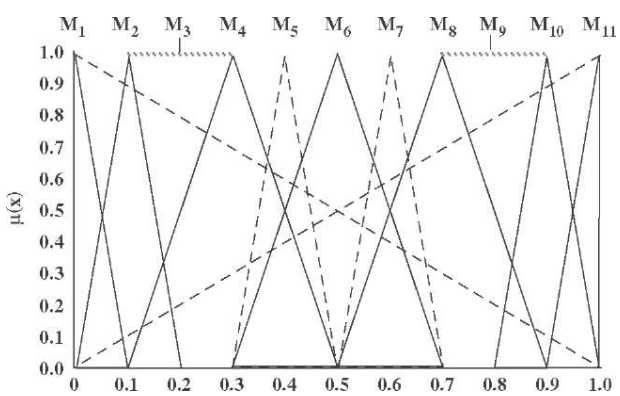

Fig. 1. Linguistic terms into their corresponding fuzzy

Table 2

Conversion of linguistic terms into fuzzy scores (11-point scale)

\begin{tabular}{ccc}
\hline Linguistic term & Fuzzy no. & Crisp no. \\
\hline Exceptionally low & $\mathrm{M}_{1}$ & 0.045 \\
Extremely low & $\mathrm{M}_{2}$ & 0.135 \\
Very low & $\mathrm{M}_{3}$ & 0.255 \\
Low & $\mathrm{M}_{4}$ & 0.335 \\
Below average & $\mathrm{M}_{5}$ & 0.410 \\
Average & $\mathrm{M}_{6}$ & 0.500 \\
Above average & $\mathrm{M}_{7}$ & 0.590 \\
High & $\mathrm{M}_{8}$ & 0.665 \\
Very high & $\mathrm{M}_{9}$ & 0.745 \\
Extremely high & $\mathrm{M}_{10}$ & 0.865 \\
Exceptionally high & $\mathrm{M}_{11}$ & 0.955 \\
\hline
\end{tabular}

Step 2: Decision matrix is normalized:

Normalization is done to compare the attribute data on the same scale. After normalization the comparison of data becomes easier. Normalization of data is done according to equations 1 and 2 as mentioned in AHP methodology.

Step 3: Relative importance of attributes:

The attributes are analyzed for the relative significance with regard to the objective as done in AHP approach.

Step 4: Development of alternative selection attribute matrix:

To achieve this the normalized values for attributes data are kept as the diagonal elements for the respective alternative. The matrix thus formed is denoted by ' $\mathrm{P}$ ' as shown in Eq. (3).

$$
P=\left[\begin{array}{cccccc}
A_{1} & p_{12} & p_{13} & \ldots & \ldots & p_{1 N} \\
p_{21} & A_{2} & p_{23} & \ldots & \ldots & p_{2 N} \\
p_{31} & p_{32} & A_{3} & \ldots & \ldots & p_{3 N} \\
\ldots & \ldots & \ldots & \ldots & \ldots & \ldots \\
p_{M 1} & p_{M 2} & p_{M 3} & \ldots & \ldots & A_{M N}
\end{array}\right]
$$

where, $\left[\mathrm{A} 1 ; \mathrm{A} 2 ; \mathrm{A} 3 ; \ldots \ldots, \mathrm{A}_{\mathrm{MN}}\right]$ are the normalized values of attributes for the respective alternative. The off-diagonal elements $\mathrm{p}_{i j}$ represent the relative importance of $\mathrm{i}^{\text {th }}$ attribute over $\mathrm{j}^{\text {th }}$ attribute on AHP scale.

Step 5: Calculation of permanent function value of the alternative selection attribute matrix for each alternative:

The permanent function value of the alternative selection attribute matrix ' $\mathrm{P}$ ' is calculated for every alternative. It is calculated in the same way but here all the determinant terms are considered as positive 
terms. Thus the whole information is provided by the permanent value and there is no loss. This is denoted by per $(\mathrm{P})$ and is known as the index score for the corresponding alternative.

Step 6: Ranking of alternatives:

The ranking of alternatives is done according to the permanent function value of the alternative selection attribute matrix, i.e., per (P), also known as index score (V Jain \& Ajmera, 2018). The alternative for which the value of index score is highest is on the top and the best option for the decision-making problems.

\subsection{Improved ELECTRE}

ELECTRE is one of the generally accepted techniques for multiple attributes decision making in several areas. Various researchers have applied it in different fields. Rehman and Subash Babu (2009) selected manufacturing system by ELECTRE method. Leyva-Lopez and Fernandez-Gonzalez (2003) used ELECTRE for problems involving group decision making. A Shanian and Savadogo (2009) and Ali Shanian, Milani, Carson, and Abeyaratne (2008) used this approach for the selection of material. Montazer, Saremi, and Ramezani (2009) and Sevkli (2010) used ELECTRE for vendor selection. Khandan, Maghsoudipour, and Vosoughi (2011) ranked the working shift groups in a petrochemical company in Iran with the help of ELECTRE. The main focus of the researchers is upon the quantitative attributes only, but the fuzzy and/or linguistic attributes have not been tried considerably. The outranking method ELimination Et Choix Traduisant la REalité (ELECTRE) i.e. ELimination and Choice Expressing the Reality, was given by Roy (1991).

Just like other approaches for outranking, ELECTRE also involves pairwise comparison of all the alternatives to analyze partial binary relationships indicating the strength by which one alternative can be preferred above another. The ELECTRE method is a highly efficient multiple attribute decision making method which also considers uncertainty and ambiguity, which are generally present in data generated by forecasting and approximations. Three different threshold values are to be defined for this purpose which include the thresholds of preference (p), indifference (q), and veto (v) so that any mistakes due to minor and less significant differences in the outranking relationships can be avoided. These three thresholds are explained in the Table 3 (Rao, 2013).

\section{Table 3}

Threshold Values

\begin{tabular}{cc}
\hline Thresholds & Description \\
\hline Preference threshold $(\mathrm{p})$ & $\begin{array}{c}\text { It is a difference of objective values of an attribute above which the decision maker strongly prefers an alter- } \\
\text { native over other for the given attribute. Alternative } \mathrm{b} \text { is strictly preferred to alternative a in terms of attribute } \\
\mathrm{i} \text { if, } \mathrm{fi}(\mathrm{b}) \geq \mathrm{fi}(\mathrm{a})+\mathrm{p} .\end{array}$ \\
$\begin{array}{c}\text { It is a difference of attribute values beneath which the decision maker is indifferent between two alternatives } \\
\text { for the given attribute. Alternative } \mathrm{b} \text { is indifferent to alternative a in terms of attribute } \mathrm{i} \text { if, fi(b) }<\mathrm{fi}(\mathrm{a})+\mathrm{q} \text {. }\end{array}$ \\
$\begin{array}{c}\text { It blocks the outranking relationship between alternatives for the given attribute. Alternative a cannot outrank } \\
\text { alternative } \mathrm{b} \text { if the performance of b exceeds that of a by an amount greater than the veto threshold, i.e. fi(b) } \\
\geq \mathrm{fi}(\mathrm{a})+\mathrm{v} .\end{array}$ \\
\hline
\end{tabular}

ELECTRE method in its basic form can successfully deal with quantitative attributes. However, to deal with the attributes which are qualitative in nature (where quantitative values are not present); a ranked value from a fuzzy conversion scale (Table 1) is judged and used. After representing a qualitative attribute on a scale the pairwise comparison of alternatives can be done in the same way as done for the quantitative attributes. The methodology of improved ELECTREE for the problems involving decision making in the manufacturing sector is described below (Rao, 2013):

Step 1: Frame a decision table using the information available regarding the alternatives and attributes in the same way as done in AHP methodology (step - 1). ELECTRE method is improved by incorporating a fuzzy conversion scale because the basic ELECTRE method cannot deal with the qualitative attributes. 
Step 2: The basic ELECTRE method also lacks in making decisions regarding relative importance weights of the attributes systematically. Therefore, in the current study, AHP procedure is used for calculating the relative importance weights as described in the AHP approach section.

Step 3: Calculate the preference threshold values i.e. p, indifference threshold i.e. q, and veto threshold i.e. $v$.

These are calculated as per equation below:

$\mathrm{p}=$ (biggest value of the attribute - smallest value of the attribute) $\times 0.6$ (because it is assumed that $\mathrm{p}$ is $60 \%$ of the maximum difference in the values of attribute)

$\mathrm{q}=$ (biggest value of the attribute - smallest value of the attribute) $\times 0.3$ (because it is assumed that $\mathrm{p}$ is $30 \%$ of the maximum difference in the values of attribute)

$\mathrm{v}=$ (biggest value of the attribute - smallest value of the attribute) $\times 1.2$ (because it is assumed that $\mathrm{p}$ is $120 \%$ of the maximum difference in the values of attribute)

Step 4: After the calculation of weights, the operational implementation of the out-ranking principles of improved ELECTRE is now described, assuming that all the attributes have to be beneficial (i.e. higher value is desired). If $\mathrm{f} j(a 1)$ is defined as the score of alternative " $a 1$ " on attribute $j$ and $w j$ represents the weight of attribute $j$, the concordance index $C(a 1, a 2)$ is defined as follows:

$$
C(a 1, \mathrm{a} 2)=\frac{1}{W} \sum_{j=1}^{M} w_{j} c_{j}(a 1, a 2), \text { where } \mathrm{W}=\sum_{j=1}^{M} w_{j}
$$

where

$$
c_{j}(a 1, a 2)=\left[\begin{array}{ll}
1, & \text { if } f_{j}(a 1)+q_{j} \geq f_{j}(a 2) \\
0, & \text { if } f_{j}(a 1)+p_{j} \leq f_{j}(a 2), \\
\frac{p_{j}+f_{j}(\mathrm{a} 1)-f_{j}(a 2)}{p_{j}-q_{j}} \text { otherwise. } j=1,2, \ldots, M
\end{array}\right.
$$

The concordance index $\mathrm{C}(\mathrm{a} 1, \mathrm{a} 2)$ denotes that alternative ' $\mathrm{a} 1$ ' ' is relatively dominant above alternative "a2", taking into account the relative importance weights of the pertinent decision attributes. In case, if any attribute is non-beneficial, negative of the objective values can be considered. For calculating the discordance, a threshold namely the veto threshold, is determined. The veto threshold (vj) provides the possibility that alternative "a1" may outrank "a2" and refuse totally if, for any one attribute $\mathrm{j}$; fj $(a 2) \geq f_{j}(a 1)+v j$. The discordance index for every attribute $j$, dj $(a 1, a 2)$ is computed as:

$$
d_{j}(a 1, a 2)=\left[\begin{array}{ll}
1, & \text { if } f_{j}(a 1)+p_{j} \geq f_{j}(a 2) \\
0, & \text { if } f_{j}(a 1)+v_{j} \leq f_{j}(a 2), \\
\frac{f_{j}(\mathrm{a} 2)+f_{j}(\mathrm{a} 1)-p_{j}}{v_{j}-p_{j}} & \text { otherwise. } j=1,2, \ldots, M
\end{array}\right.
$$

The discordance index dj (a1, a2) computes the degree to which alternative "a1" is inferior than "a2". The quality of the discordance index is that any outranking of "a2 "by "a1' indicated by the concordance index may be retracted if there is any attribute for which alternative "a2" outperforms alternative "a1" by at least the veto threshold. Finally these two measures are combined in the phase of model building to generate a measure of the degree of outranking; i.e., a credibility index which evaluates the 
strength of the statement that "al is at least as good as a2"'. The degree of credibility for each pair (a1, a2) $\epsilon \mathrm{A}$ is stated as:

$$
S(a 1, a 2)=\left[\begin{array}{ll}
C(a 1, a 2), & \begin{array}{l}
\text { if, } \mathrm{d}_{j}(\mathrm{a} 1, \mathrm{a} 2) \leq \mathrm{C}(\mathrm{a} 1, \mathrm{a} 2), \forall_{j} \\
\text { where, } j \in J(a 1, a 2) \text { is the set of criteria } \\
\\
\text { such that } d_{j}(\mathrm{a} 1, \mathrm{a} 2)>\mathrm{C}(\mathrm{a} 1, \mathrm{a} 2)
\end{array} \\
C(a 1, a 2) . & \prod_{j \in J(a 1, a 2)} \frac{1-d_{j}(a 1, a 2)}{1-C(a 1, a 2)} \quad \text { otherwise. }
\end{array}\right.
$$

This finalizes the formation of the outranking model. After this the hierarchical structure of the alternative solutions from the elements of the credibility matrix is created. The hierarchy rank is determined by computing the superiority ratio for all the alternatives. The superiority ratio is assessed from the credibility matrix and is the fraction of the elements' sum of each alternative's respective column. The numerator represents the total dominance of the specific alternative over the remaining alternatives and the denominator represents the dominance of the remaining alternatives over the former. The numerator for each alternative is also known as concordance credibility and is calculated as follows:

$$
\begin{aligned}
\phi^{+}(\mathrm{a} 1) & =\sum_{a 2 \in A} S(a 1, a 2) \\
\phi^{-}(\mathrm{a} 1) & =\sum_{a 2 \in A} S(a 2, a 1) \\
R(\mathrm{a} 1) & =\frac{\phi^{+}(\mathrm{a} 1)}{\phi^{-}(\mathrm{a} 1)}
\end{aligned}
$$

\section{Ranking of Performance factors}

Ranking of performance factors are done as per methodology discussed in section 2.

\subsection{Analysis by AHP}

Different steps of this process are described below:

1. Factors were ranked based on six attributes. The hierarchical structure is developed by the ranking of factors at the top level, six attributes at the intermediate and three alternatives at the bottom level.

2. Relative significance of the attributes with regard to objective is calculated as under:

a. Pair-wise comparisons are performed using the judgments based upon Pair-wise comparison

\begin{tabular}{|c|c|c|c|c|c|c|c|}
\hline \multirow[t]{2}{*}{ Sr.No. } & \multirow[t]{2}{*}{ Factors / Variables } & 1 & 2 & 3 & 4 & 5 & 6 \\
\hline & & Automation & $\begin{array}{c}\text { Use of auto- } \\
\text { mated material } \\
\text { handling de- } \\
\text { vices }\end{array}$ & $\begin{array}{l}\text { Increase ma- } \\
\text { chine utiliza- } \\
\text { tion }\end{array}$ & $\begin{array}{l}\text { Manufacturing lead } \\
\text { time \& set up time } \\
\text { reduction }\end{array}$ & $\begin{array}{l}\text { Flexible fix- } \\
\text { turing }\end{array}$ & $\begin{array}{l}\text { Reduction in } \\
\text { scrap }\end{array}$ \\
\hline 1 & Automation & 1 & $1 / 2$ & 5 & 3 & $1 / 3$ & 3 \\
\hline 2 & $\begin{array}{l}\text { Use of automated material } \\
\text { handling devices }\end{array}$ & 2 & 1 & 2 & 2 & $1 / 3$ & 2 \\
\hline 3 & $\begin{array}{c}\text { Increase machine utiliza- } \\
\text { tion }\end{array}$ & $1 / 5$ & $1 / 2$ & 1 & $1 / 2$ & $1 / 3$ & 2 \\
\hline 4 & $\begin{array}{l}\text { Manufacturing lead time } \\
\& \text { set up time reduction }\end{array}$ & $1 / 3$ & $1 / 2$ & 2 & 1 & $1 / 3$ & $1 / 2$ \\
\hline 5 & Flexible fixturing & 3 & 3 & 3 & 3 & 1 & 3 \\
\hline 6 & Reduction in scrap & $1 / 3$ & $1 / 2$ & $1 / 2$ & 2 & $1 / 3$ & 1 \\
\hline
\end{tabular}
scale developed by Thomas L Saaty (2000). It is shown in Table 4 as a pairwise matrix.

\section{Table 4}

Pairwise matrix

b. The geometric mean of $\mathrm{i}$-th row and attributes weights are calculated as described in "AHP approach" section (step 2) and these weights will be utilized in the matrix A2. The weights of these attributes are depicted in Table 5. 
Table 5

Weights of attributes

\begin{tabular}{ccccccc}
\hline Attributes & 1 & 2 & 3 & 4 & 5 & 6 \\
\hline Weight & 0.199 & 0.188 & 0.081 & 0.088 & 0.356 & 0.088 \\
\hline
\end{tabular}

c. Matrices A3 and A4 are calculated along with the maximum Eigenvalue $k_{\max }$ i.e. 6.067 that is the average of A4 matrix.

d. Consistency index is calculated as $\mathrm{CI}=(\mathrm{kmax}-\mathrm{M}) /(\mathrm{M}-1)=0.121$.

e. $\mathrm{RI}$ for the 6 attributes is taken $=1.25$ (T.L. Saaty \& Tran, 2007).

f. The consistency ratio is computed as $(\mathrm{CR})=\mathrm{CI} / \mathrm{RI}=0.0971$. $\mathrm{CR}=0.0971$. CR less than or equal to 0.1 is accepted.

3. In this step, the attributes are defined in linguistic terms which are further transformed into fuzzy values as described in the fuzzy MADM methodology. Quantitative values are provided in Table 6. Normalization of the quantitative values of attributes is done which is presented in Table 7.

Table 6

Crisp No.

\begin{tabular}{|c|c|c|c|c|c|c|c|}
\hline & & 1 & 2 & 3 & 4 & 5 & 6 \\
\hline & & Automation & $\begin{array}{c}\text { Use of } \\
\text { automated } \\
\text { material } \\
\text { handling devices }\end{array}$ & $\begin{array}{l}\text { Increase } \\
\text { machine } \\
\text { utilization }\end{array}$ & $\begin{array}{l}\text { Manufacturing } \\
\text { lead time \& set up } \\
\text { time reduction }\end{array}$ & $\begin{array}{l}\text { Flexible } \\
\text { fixturing }\end{array}$ & $\begin{array}{l}\text { Reduction in } \\
\text { scrap }\end{array}$ \\
\hline 1 & Productivity & 0.995 & 0.865 & 0.745 & 0.745 & 0.865 & 0.745 \\
\hline 2 & Flexibility & 0.865 & 0.745 & 0.745 & 0.665 & 0.865 & 0.665 \\
\hline 3 & Quality & 0.745 & 0.665 & 0.665 & 0.665 & 0.745 & 0.865 \\
\hline
\end{tabular}

Table 7

Normalization

\begin{tabular}{|c|c|c|c|c|c|c|c|}
\hline & & 1 & 2 & 3 & 4 & 5 & 6 \\
\hline & & Automation & $\begin{array}{c}\text { Use of } \\
\text { automated } \\
\text { material } \\
\text { handling } \\
\text { devices }\end{array}$ & $\begin{array}{l}\text { Increase } \\
\text { machine } \\
\text { utilization }\end{array}$ & $\begin{array}{l}\text { Manufacturing lead } \\
\text { time \& set up time } \\
\text { reduction }\end{array}$ & $\begin{array}{l}\text { Flexible } \\
\text { fixturing }\end{array}$ & $\begin{array}{l}\text { Reduction in } \\
\text { scrap }\end{array}$ \\
\hline 1 & Productivity & 1.000 & 1.000 & 1.000 & 1.000 & 1.000 & 0.861 \\
\hline 2 & Flexibility & 0.869 & 0.861 & 1.000 & 0.893 & 1.000 & 0.769 \\
\hline 3 & Quality & 0.749 & 0.769 & 0.893 & 0.893 & 0.861 & 1.000 \\
\hline
\end{tabular}

4. Multiply the relative normalized weight (wj) of each attribute with its respective normalized weight value to calculate the total composite performance scores for the alternatives. The overall or composite performance scores are shown in Table 8. Ranking of the factors is done depending upon the scores which is also depicted in Table 8.

Table 8

The overall scores of alternatives

\begin{tabular}{cccc}
\hline Sr. No. & Alternatives & Overall scores & Ranking \\
\hline 1 & Productivity & 0.988 & 1 \\
2 & Flexibility & 0.918 & 2 \\
3 & Quality & 0.839 & 3 \\
\hline
\end{tabular}

\subsection{Analysis by $C M B A$}

Step1: Decision matrix

The Table 5 exhibit the problem's decision matrix which have 3 alternative as performance factors of FMS and six selection attributes. Data are qualitative in nature and therefore converted in quantitative with the help of fuzzy set as discussed in Table 1 and Fig. 1. 
Step 2: First of all, it is decided if the data is beneficial or non-beneficial. In this research, the data is beneficial, so Eq. (1) has been used for the normalization of data. The Table 7 exhibits the normalization decision matrix.

Step 3: Importance of attributes (relatively)

The importance of the attributes is same as used in analytic hierarchy process. The relative weights of the attributes are depicted in Table 5.

Step 5: Development of "alternative selection attribute matrix" for each alternative

The "alternative selection attribute matrix" is developed by placing the attribute's normalized values for the respective alternative as the diagonal elements. The "alternative selection attribute matrix" for alternatives is shown below in Table 9 .

\section{Table 9}

Alternative selection attribute matrix (For Alternative 1)

\begin{tabular}{|c|c|c|c|c|c|c|c|}
\hline $\begin{array}{c}\text { F1 } \\
\text { Sr.no. }\end{array}$ & Factors / Variables & 1 & 2 & 3 & 4 & 5 & 6 \\
\hline & & Automation & $\begin{array}{c}\text { Use of automated } \\
\text { material handling } \\
\text { devices }\end{array}$ & $\begin{array}{l}\text { Increase } \\
\text { machine } \\
\text { utilization }\end{array}$ & $\begin{array}{l}\text { Manufacturing lead } \\
\text { time \& set up time } \\
\text { reduction }\end{array}$ & $\begin{array}{l}\text { Flexible } \\
\text { fixturing }\end{array}$ & $\begin{array}{l}\text { Reduction in } \\
\text { scrap }\end{array}$ \\
\hline 1 & Automation & 1.00 & 0.50 & 5.00 & 3.00 & 0.33 & 3.00 \\
\hline 2 & $\begin{array}{l}\text { Use of automated material handling de- } \\
\text { vices }\end{array}$ & 2.00 & 1.00 & 2.00 & 2.00 & 0.33 & 2.00 \\
\hline 3 & Increase machine utilization & 0.20 & 0.50 & 1.00 & 0.50 & 0.33 & 2.00 \\
\hline 4 & $\begin{array}{l}\text { Manufacturing lead time \& set up time } \\
\text { reduction }\end{array}$ & 0.33 & 0.50 & 2.00 & 1.00 & 0.33 & 0.50 \\
\hline 5 & Flexible fixturing & 3.00 & 3.00 & 3.00 & 3.00 & 1.00 & 3.00 \\
\hline 6 & Reduction in scrap & 0.33 & 0.50 & 0.50 & 2.00 & 0.33 & 0.86 \\
\hline
\end{tabular}

For Alternative 2:

\begin{tabular}{|c|c|c|c|c|c|c|c|}
\hline $\begin{array}{c}\text { F2 } \\
\text { Sr.no. }\end{array}$ & Factors / Variables & 1 & 2 & 3 & 4 & 5 & 6 \\
\hline & & Automation & $\begin{array}{c}\text { Use of automated } \\
\text { material handling } \\
\text { devices }\end{array}$ & $\begin{array}{l}\text { Increase ma- } \\
\text { chine utiliza- } \\
\text { tion }\end{array}$ & $\begin{array}{l}\text { Manufacturing } \\
\text { lead time \& set up } \\
\text { time reduction }\end{array}$ & $\begin{array}{l}\text { Flexible } \\
\text { fixturing }\end{array}$ & $\begin{array}{l}\text { Reduction in } \\
\text { scrap }\end{array}$ \\
\hline 1 & Automation & 0.87 & 0.50 & 5.00 & 3.00 & 0.33 & 3.00 \\
\hline 2 & $\begin{array}{l}\text { Use of automated mate- } \\
\text { rial handling devices }\end{array}$ & 2.00 & 0.86 & 2.00 & 2.00 & 0.33 & 2.00 \\
\hline 3 & $\begin{array}{c}\text { Increase machine utiliza- } \\
\text { tion }\end{array}$ & 0.20 & 0.50 & 1.00 & 0.50 & 0.33 & 2.00 \\
\hline 4 & $\begin{array}{l}\text { Manufacturing lead time } \\
\& \text { set up time reduction }\end{array}$ & 0.33 & 0.50 & 2.00 & 0.89 & 0.33 & 0.50 \\
\hline 5 & Flexible fixturing & 3.00 & 3.00 & 3.00 & 3.00 & 1.00 & 3.00 \\
\hline 6 & Reduction in scrap & 0.33 & 0.50 & 0.50 & 2.00 & 0.33 & 0.77 \\
\hline
\end{tabular}

For Alternative 3:

\begin{tabular}{|c|c|c|c|c|c|c|c|}
\hline $\begin{array}{c}\text { F3 } \\
\text { Sr.no. }\end{array}$ & Factors / Variables & 1 & 2 & 3 & 4 & 5 & 6 \\
\hline & & Automation & $\begin{array}{c}\text { Use of automated } \\
\text { material handling } \\
\text { devices }\end{array}$ & $\begin{array}{l}\text { Increase ma- } \\
\text { chine utiliza- } \\
\text { tion }\end{array}$ & $\begin{array}{l}\text { Manufacturing } \\
\text { lead time \& set up } \\
\text { time reduction }\end{array}$ & $\begin{array}{l}\text { Flexible } \\
\text { fixturing }\end{array}$ & $\begin{array}{l}\text { Reduction in } \\
\text { scrap }\end{array}$ \\
\hline 1 & Automation & 0.75 & 0.50 & 5.00 & 3.00 & 0.33 & 3.00 \\
\hline 2 & $\begin{array}{l}\text { Use of automated } \\
\text { material handling } \\
\text { devices }\end{array}$ & 2.00 & 0.77 & 2.00 & 2.00 & 0.33 & 2.00 \\
\hline 3 & $\begin{array}{c}\text { Increase machine } \\
\text { utilization }\end{array}$ & 0.20 & 0.50 & 0.89 & 0.50 & 0.33 & 2.00 \\
\hline 4 & $\begin{array}{l}\text { Manufacturing lead } \\
\text { time \& set up time } \\
\text { reduction }\end{array}$ & 0.33 & 0.50 & 2.00 & 0.89 & 0.33 & 0.50 \\
\hline 5 & Flexible fixturing & 3.00 & 3.00 & 3.00 & 3.00 & 0.86 & 3.00 \\
\hline 6 & Reduction in scrap & 0.33 & 0.50 & 0.50 & 2.00 & 0.33 & 1.00 \\
\hline
\end{tabular}

Step 5: Find the permanent function value (or index score) i.e. P for the "alternative selection attribute matrix" for each alternative.

The permanent function value (or index score) i.e. P for the "alternative selection attribute matrix" for each alternative is calculated. The index score values ' $\mathrm{P}$ ' for the alternatives acquired are:

P $1=1396$ 
P $2=1304$

P $3=1261$

The calculation of permanent function is done in $\mathrm{C}^{++}$. Results are shown in figure $2,3 \& 4$ for alternative $1,2 \& 3$ respectively.

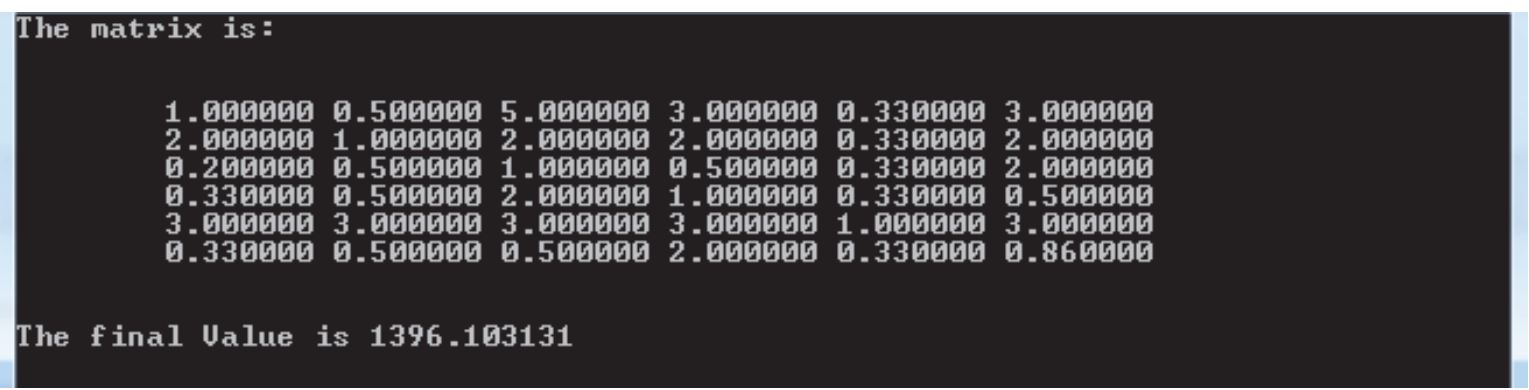

Fig. 2. Permanent function value for alternative 1

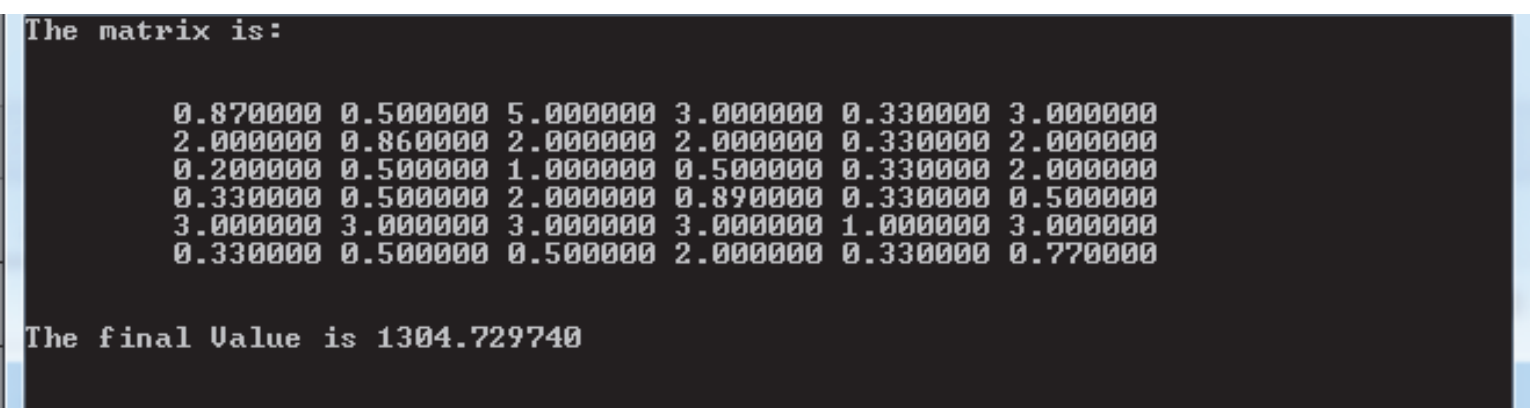

Fig. 3. Permanent function value for alternative 2

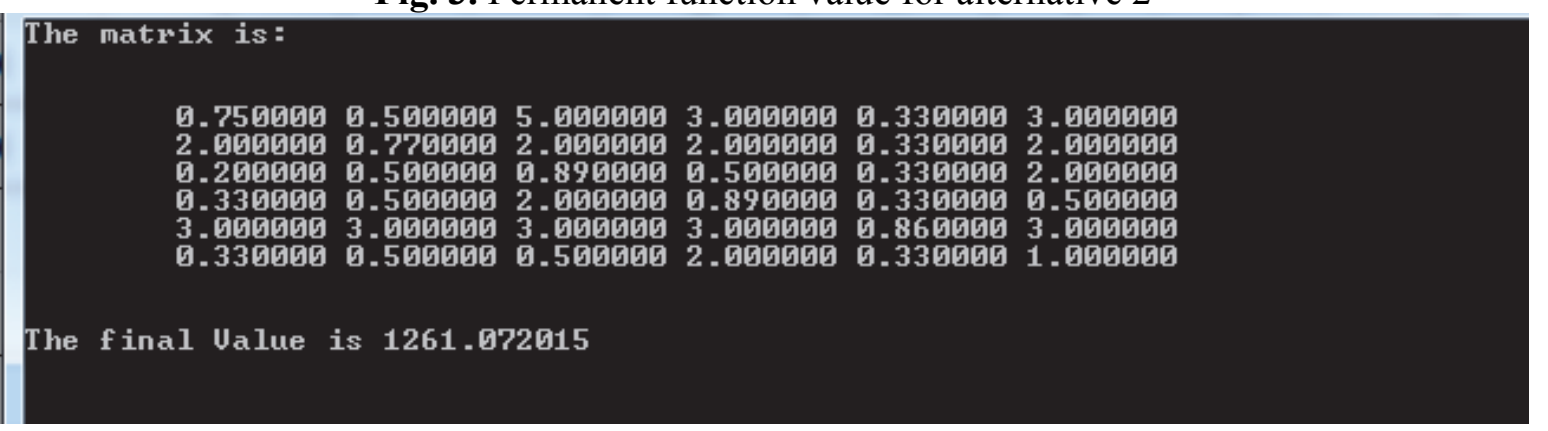

Fig. 3. Permanent function value for alternative 3

The ranking of factor (alternatives) is shown in Table 10.

Table 10

Ranking of alternatives

\begin{tabular}{cccc}
\hline Alternative & Name of Factor & Permanent function value & Ranking \\
\hline P1 & Productivity & 1396 & 1 \\
P2 & Flexibility & 1304 & 2 \\
P3 & Quality & 1261 & 3 \\
\hline
\end{tabular}

\subsection{Analysis by improved ELECTRE method}

The evaluation of performance factor of FMS is solved by using improved ELECTRE method as: 
Step-1: The attributes related to the problem are identified and available alternatives with their corresponding objective values are presented in form of a matrix as discussed in Table 2. Attributes values are qualitative in nature. So, the qualitative objective values are converted to the attribute quantitative values by using fuzzy set and crisp no. is obtained as per Fig. 1 and Table 2.

Step-2: AHP approach is applied to compute the attribute weights. In this case, same attributes weights are taken as in AHP method. So, the results can be compared by other methods. It is exhibited in the Table 5.

Step 3: Quantify the p, q and v values:

Values of $\mathrm{p}, \mathrm{q}$ and $\mathrm{v}$ are exhibited in Table 11.

Table 11

Values of $p, q$ and $v$

\begin{tabular}{ccccccc}
\hline & 1 & 2 & 3 & 4 & 5 & 6 \\
\cline { 2 - 7 } & Automation & $\begin{array}{c}\text { Use of } \\
\text { automated mate- } \\
\text { rial handling } \\
\text { devices }\end{array}$ & $\begin{array}{c}\text { Increase } \\
\text { machine } \\
\text { utilization }\end{array}$ & $\begin{array}{c}\text { Manufacturing } \\
\text { lead time \& } \\
\text { set up time } \\
\text { reduction }\end{array}$ & $\begin{array}{c}\text { Flexible } \\
\text { fixturing }\end{array}$ & $\begin{array}{c}\text { Reduction } \\
\text { in scrap }\end{array}$ \\
\hline preference threshold, p & 0.15 & 0.12 & 0.048 & 0.048 & 0.072 & 0.12 \\
indifference threshold, q & 0.075 & 0.06 & 0.024 & 0.024 & 0.036 & 0.06 \\
veto threshold, v & 0.3 & 0.24 & 0.096 & 0.096 & 0.144 & 0.24 \\
\hline Weight, w & 0.199 & 0.188 & 0.081 & 0.088 & 0.356 & 0.088 \\
\hline
\end{tabular}

Step-4: The ELECTRE method is then followed and first of all using concordance matrices for each attribute is obtained. Concordance matrices for each attributes are shown in Table 12.

Table 12

Concordance matrices for each attribute

For automation:

\begin{tabular}{cccc}
\hline & Productivity & Flexibility & Quality \\
\hline Productivity & 1 & 1 & 1 \\
Flexibility & 0.267 & 1 & 1 \\
Quality & 0 & 0.4 & 1 \\
\hline
\end{tabular}

For use of automated material handling devices:

\begin{tabular}{cccc}
\hline & Productivity & Flexibility & Quality \\
\hline Productivity & 1 & 1 & 1 \\
Flexibility & 0.4 & 1 & 1 \\
Quality & 0 & 0.933 & 1 \\
\hline
\end{tabular}

For increase machine utilization:

\begin{tabular}{cccc}
\hline & Productivity & Flexibility & Quality \\
\hline Productivity & 1 & 1 & 1 \\
Flexibility & 1 & 1 & 1 \\
Quality & 0.933 & 0.933 & 1 \\
\hline
\end{tabular}

For manufacturing lead time and setup time reduction:

\begin{tabular}{cccc}
\hline & Productivity & Flexibility & Quality \\
\hline Productivity & 1 & 1 & 1 \\
Flexibility & 0.933 & 1 & 1 \\
Quality & 0.933 & 1 & 1 \\
\hline
\end{tabular}


For flexible fixturing:

\begin{tabular}{cccc}
\hline & Productivity & Flexibility & Quality \\
\hline Productivity & 1 & 1 & 1 \\
Flexibility & 1 & 1 & 1 \\
Quality & 0.4 & 0.4 & 1 \\
\hline
\end{tabular}

For reduction in scrap:

\begin{tabular}{cccc}
\hline & Productivity & Flexibility & Quality \\
\hline Productivity & 1 & 1 & 0.4 \\
Flexibility & 0.933 & 1 & 0 \\
Quality & 1 & 1 & 1 \\
\hline
\end{tabular}

For these calculations, values of preference threshold and indifference thresholds are required. Also, veto threshold is required for the calculation of discordance values. These threshold values are calculated as shown in Table 11. Similarly concordance matrices are obtained for all the remaining attributes. Then, the overall concordance matrix $\mathrm{C}$ can be calculated as shown by aggregation of all six concordance matrices of six attributes in Table 13.

Table 13

The overall concordance matrix

\begin{tabular}{cccc}
\hline & Productivity & Flexibility & Quality \\
\hline Productivity & 1 & 1 & 0.947216391 \\
Flexibility & 0.729211927 & 1 & 0.912027318 \\
\hline Quality & 0.387736201 & 0.648965077 & 1 \\
\hline
\end{tabular}

After calculating overall concordance matrix $\mathrm{C}$, discordance matrices are calculated for each attribute using Eq. 5. This is similar to calculation of concordance matrices of attributes but here veto threshold comes into picture. Discordance matrices are presented in the Table 14.

Table 14

Discordance matrices are calculated for each attribute

For automation:

\begin{tabular}{cccc} 
& Productivity & Flexibility & Quality \\
Productivity & 1 & 0 & 0 \\
Flexibility & 0 & 1 & 0 \\
Quality & 0.667 & 0 & 1 \\
\hline
\end{tabular}

For use of automated material handling devices:

\begin{tabular}{cccc}
\hline & Productivity & Flexibility & Quality \\
\hline Productivity & 1 & 0 & 0 \\
Flexibility & 0 & 1 & 0 \\
Quality & 0.667 & 0 & 1 \\
\hline
\end{tabular}

For increase machine utilization:

\begin{tabular}{cccc}
\hline & Productivity & Flexibility & Quality \\
\hline Productivity & 1 & 0 & 0 \\
Flexibility & 0 & 1 & 0 \\
Quality & 0.667 & 0.667 & 1 \\
\hline
\end{tabular}

For manufacturing lead time and setup time reduction:

\begin{tabular}{cccc}
\hline & Productivity & Flexibility & Quality \\
\hline Productivity & 1 & 0 & 0 \\
Flexibility & 0.667 & 1 & 0 \\
Quality & 0.667 & 0 & 1 \\
\hline
\end{tabular}


For flexible fixturing:

\begin{tabular}{cccc}
\hline & Productivity & Flexibility & Quality \\
\hline Productivity & 1 & 0 & 0 \\
Flexibility & 0 & 1 & 0 \\
Quality & 0.667 & 0.667 & 1 \\
\hline
\end{tabular}

For reduction in scrap:

\begin{tabular}{cccc}
\hline & Productivity & Flexibility & Quality \\
\hline Productivity & 1 & 0 & 0 \\
Flexibility & 0 & 1 & 0.667 \\
Quality & 0 & 0 & 1 \\
\hline
\end{tabular}

Using Eq. (6), the credibility index matrix $\mathrm{S}$ is obtained and shown in Table 15.

Table 15

The Credibility index matrix

\begin{tabular}{cccc}
\hline & Productivity & Flexibility & Quality \\
\hline Productivity & 1 & 1 & 0.947216391 \\
Flexibility & 0.729211927 & 1 & 0.912027318 \\
Quality & 0.211 & 0.615684817 & 1 \\
\hline
\end{tabular}

Finally, the concordance credibility, discordance credibility and superiority ratio values are obtained using Eq. (7-9) as depicted in the Table 16.

Table 16

The Concordance credibility, discordance credibility and superiority ratio and ranking of factors

\begin{tabular}{ccccc}
\hline Factors & concordance credibility & Discordance credibility & superiority ratio & Rank \\
\hline Productivity & 2.947 & 1.940 & 1.519 & 1 \\
Flexibility & 2.641 & 2.616 & 1.010 & 2 \\
Quality & 1.827 & 2.859 & 0.639 & 3 \\
\hline
\end{tabular}

The ordering of the alternatives is obtained by sorting the alternatives in decreasing order of the superiority ratio values. The ranking obtained using ELECTRE in this case is 1-2-3. This ranking is same as calculated by AHP and CMBA.

\section{Discussion and Conclusion}

Combinatorial mathematics based approach (CMBA), ELECTRE and AHP appraoch are proposed in the present paper to rank the performance factors of the FMS taking into account the qualitative attributes which are transformed in qualitative attributes with the help of fuzzy logic. The important factors of flexible manufacturing system have been taken which affect its performance viz. productivity, flexibility, quality. Besides this six attributes which affect these factors are also taken.

For prioritzation, subjective weights are used and these have been calculated by AHP methodology. Ranking of factors have been done by AHP, CMBA and ELECTRE. CMBA is a MADM approach which is the combination of AHP and GTMA methodology. In this approach, attributes weights are calculated by AHP and the index scores are calculated by GTMA. A permanent function is used to find the index score. A permanent function is quantified by a $\mathrm{C}^{++}$program. Results show that ranking by AHP, CMBA and ELECTRE is similar i.e. productivity is assigned rank 1, flexibility rank 2 and quality is assigned rank 3. It is exhibited in Fig. 5. 


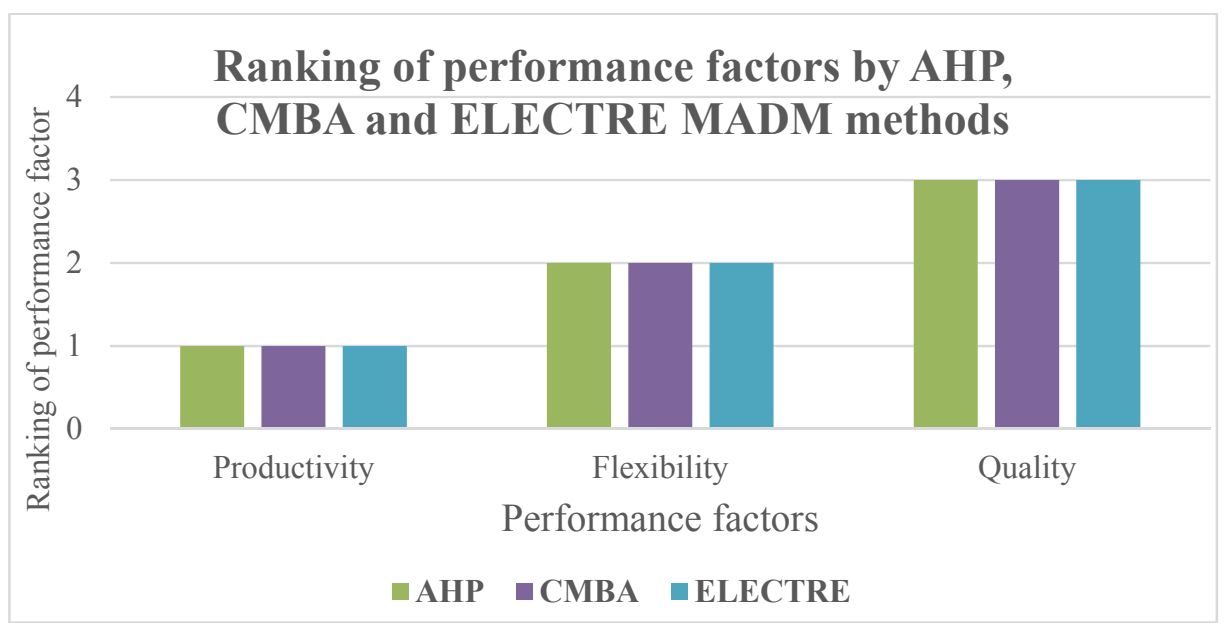

Fig. 5. Ranking of performance factors

So, it is concluled that to increase the performance of FMS, managers should focus more on the productivity. The results of AHP, CMBA and ELECRE are validated by comparing the results of all the methologies. Also, a very high Spearman's rank correlation exists among the methods used which is shown in Fig. 6.

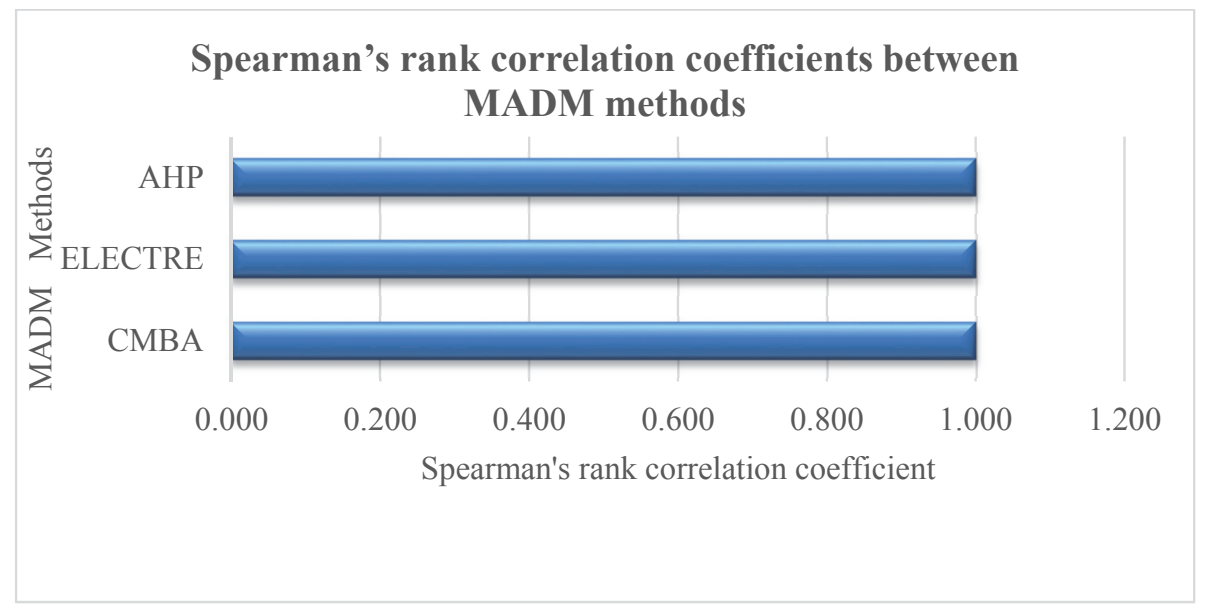

Fig. 6. Spearman's rank correlation coefficients between MADM methods

These methodologies are very rational, easy and simple to apply. They can be implemented and extended to any other situations which involve decision making in the manufacturing industry.

\section{References}

Al-Ahmari, A. M. A. (2008). A methodology for selection and evaluation of advanced manufacturing technologies. International Journal of Computer Integrated Manufacturing, 21(7), 778-789.

Bayazit, O. (2005). Use of AHP in decision-making for flexible manufacturing systems. Journal of Manufacturing Technology Management, 16(7), 808-819.

Dağdeviren, M. (2008). Decision making in equipment selection: an integrated approach with AHP and PROMETHEE. Journal of Intelligent Manufacturing, 19(4), 397-406.

Gothwal, S., \& Raj, T. (2016). Analyzing the factors affecting the flexibility in FMS using weighted interpretive structural modeling (WISM) approach. International Journal of System Assurance Engineering and Management, 8(2), 1-15. 
Gunasekaram, A., Goyal, S. K., MArtikainen, T., \& Yli-Olli, P. (1998). Total quality management: a new perspective for improving quality and productivity. International Journal of Quality \& Reliability Management, 15(8/9), 947-968.

Jain, V. (2018). Application of combined MADM methods as MOORA and PSI for ranking of FMS performance factors. Benchmarking: An International Journal, 25(6), 1903-1920.

Jain, V., \& Ajmera, P. (2018). Quantifying the variables affecting Indian medical tourism sector by graph theory and matrix approach. Management Science Letters, 8(4), 225-240.

Jain, V., \& Raj, T. (2013a). Evaluating the Variables Affecting Flexibility in FMS by Exploratory and Confirmatory Factor Analysis. Global Journal of Flexible Systems Management, 14(4), 181-193.

Jain, V., \& Raj, T. (2013b). Evaluation of flexibility in FMS using SAW and WPM. Decision Science Letters, 2(4), 223-230.

Jain, V., \& Raj, T. (2013c). Ranking of Flexibility in Flexible Manufacturing System by Using a Combined Multiple Attribute Decision Making Method. Global Journal of Flexible Systems Management, 14(3), 125-141.

Jain, V., \& Raj, T. (2014a). Evaluation of flexibility in FMS by VIKOR methodology. International Journal of Industrial and Systems Engineering, 18(4), 483-498.

Jain, V., \& Raj, T. (2014b). Modelling and analysis of FMS productivity variables by ISM, SEM and GTMA approach. Frontiers of Mechanical Engineering, 9(3), 218-232.

Jain, V., \& Raj, T. (2015a). Evaluating the intensity of variables affecting flexibility in FMS by graph theory and matrix approach. International Journal of Industrial and Systems Engineering, 19(2), 137-154.

Jain, V., \& Raj, T. (2015b). A hybrid approach using ISM and modified TOPSIS for the evaluation of flexibility in FMS. International Journal of Industrial and Systems Engineering, 19(3), 389-406.

Jain, V., \& Raj, T. (2015c). Modeling and analysis of FMS flexibility factors by TISM and fuzzy MICMAC. International Journal of System Assurance Engineering and Management, 6(3), 350371.

Jain, V., \& Raj, T. (2016). Modeling and analysis of FMS performance variables by ISM, SEM and GTMA approach. International Journal of Production Economics, 171(1), 84-96.

Jain, V., \& Raj, T. (2017). Tool life management of unmanned production system based on surface roughness by ANFIS. International Journal of System Assurance Engineering and Management, $8(2), 458-467$.

Jain, V., \& Soni, V. K. (2018). Modeling and analysis of FMS performance variables by fuzzy TISM. Journal of Modelling in Management.doi: https://doi.org/10.1108/JM2-03-2018-0036

Khanchanapong, T., Prajogo, D., Sohal, A. S., Cooper, B. K., Yeung, A. C., \& Cheng, T. (2014). The unique and complementary effects of manufacturing technologies and lean practices on manufacturing operational performance. International journal of production economics, 153, 191203.

Khandan, M., Maghsoudipour, M., \& Vosoughi, S. (2011). Ranking of working shift groups in an Iranian petrochemical company using ELECTRE method based on safety climate assessment results. Journal of the Chinese Institute of Industrial Engineers, 28(7), 537-542.

Leyva-Lopez, J. C., \& Fernandez-Gonzalez, E. (2003). A new method for group decision support based on ELECTRE III methodology. European journal of operational research, 148(1), 14-27.

Liu, C.-M., Hsu, H.-S., Wang, S.-T., \& Lee, H.-K. (2005). A performance evaluation model based on AHP and DEA. Journal of the Chinese Institute of Industrial Engineers, 22(3), 243-251.

Luggen, W. W. (1991). Flexible manufacturing cells and systems. Englewood Cliffs, New Jersey: Prentice Hall.

Maleki, R. A. (1991). Flexible manufacturing systems: The technology and management. Englewood Cliffs, New Jersey: Prentice Hall.

Montazer, G. A., Saremi, H. Q., \& Ramezani, M. (2009). Design a new mixed expert decision aiding system using fuzzy ELECTRE III method for vendor selection. Expert Systems with Applications, 36(8), 10837-10847. 
Pun, K. F., Chin, K. S., \& Yiu, M. Y. R. (2010). An AHP approach to assess new product development performance: An exploratory study. International Journal of Management Science and Engineering Management, 5(3), 210-218.

Raj, T., Attri, R., \& Jain, V. (2012). Modelling the factors affecting flexibility in FMS. International Journal of Industrial and Systems Engineering, 11(4), 350-374.

Rao, R. V. (2013). Decision Making in Manufacturing Environment Using Graph Theory and Fuzzy Multiple Attribute Decision Making Methods (Vol. 2). London: Springer-Verlag.

Ravikumar, M., Marimuthu, K., \& Parthiban, P. (2015). Evaluating lean implementation performance in Indian MSMEs using ISM and AHP models. International Journal of Services and Operations Management, 22(1), 21-39.

Rehman, A.-U., \& Subash Babu, A. (2009). The evaluation of manufacturing systems using concordance and disconcordance properties. International Journal of Services and Operations Management, 5(3), 326-349.

Roy, B. (1991). The outranking approach and the foundations of ELECTRE methods. Theory and decision, 31(1), 49-73.

Ruiz, M. C., Cazorla, D., Cuartero, F., \& Macia, H. (2009). Improving performance in flexible manufacturing systems. The Journal of Logic and Algebraic Programming, 78(4), 260-273.

Saaty, T. L. (1994). Fundamentals of decision making and priority theory with the analytic hierarchy process (Vol. 4922). Pittsburgh,PA: RWS publications

Saaty, T. L. (2000). Fundamentals of decision making and priority theory with the analytic hierarchy process (Vol. 6). Pittsburgh, PA: RWS Publications.

Saaty, T. L., \& Tran, L. T. (2007). On the invalidity of fuzzifying numerical judgments in the Analytic Hierarchy Process. Mathematical and Computer Modelling, 46(7), 962-975.

Sevkli, M. (2010). An application of the fuzzy ELECTRE method for supplier selection. International Journal of Production Research, 48(12), 3393-3405.

Shanian, A., Milani, A., Carson, C., \& Abeyaratne, R. (2008). A new application of ELECTRE III and revised Simos' procedure for group material selection under weighting uncertainty. KnowledgeBased Systems, 21(7), 709-720.

Shanian, A., \& Savadogo, O. (2009). A methodological concept for material selection of highly sensitive components based on multiple criteria decision analysis. Expert Systems with Applications, $36(2), 1362-1370$.

Singh, R. K., \& Sharma, M. K. (2014). Selecting competitive supply chain using fuzzy AHP and extent analysis. Journal of Industrial and Production Engineering, 31(8), 524-538. doi: $10.1080 / 21681015.2014 .999723$

Taha, Z., \& Rostam, S. (2012). A hybrid fuzzy AHP-PROMETHEE decision support system for machine tool selection in flexible manufacturing cell. Journal of Intelligent Manufacturing, 23(6), 2137-2149.

Triantaphyllou, E. (2013). Multi-criteria decision making methods: a comparative study. Dordrecht, Netherlands: Springer Science \& Business Media.

Umar, U. A., Ariffin, M., Ismail, N., \& Tang, S. (2015). Hybrid multiobjective genetic algorithms for integrated dynamic scheduling and routing of jobs and automated-guided vehicle (AGV) in flexible manufacturing systems (FMS) environment. The International Journal of Advanced Manufacturing Technology, 81(9-12), 2123-2141.

Yang, C.-C., \& Chen, B.-S. (2004). Key quality performance evaluation using fuzzy AHP. Journal of the Chinese Institute of Industrial Engineers, 21(6), 543-550.

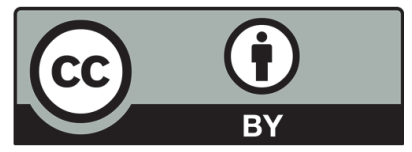

(C) 2019 by the authors; licensee Growing Science, Canada. This is an open access article distributed under the terms and conditions of the Creative Commons Attribution (CC-BY) license (http://creativecommons.org/licenses/by/4.0/). 